\title{
Development of polyclonal antiserum against movement protein from Potato leafroll virus and its application for the virus detection
}

\author{
Fang Yang ${ }^{\dagger}$, M. Rashid ${ }^{\dagger}$, Xiao-Yan Zhang, Zong-Ying Zhang, Ying Wang, Da-Wei Li, Jia-Lin Yu and Cheng-Gui Han ${ }^{*}$ (D)
}

\begin{abstract}
The serological method is one of the most important techniques extensively used in crop production to detect different pathogens, especially plant viruses. An antiserum is essential for serological tests. The $17 \mathrm{kDa}$ movement protein (MP) of Potato leafroll virus (PLRV) is related to the membranous structures and localized to the plasmodesmata, but there is no report on preparation of PLRV-MP antiserum for detection of PLRV. To prepare PLRV-MP antiserum, reverse transcription polymerase chain reaction (RT-PCR) was carried out to amplify the PLRV-MP gene, which was constructed into a prokaryotic vector to express the protein in Escherichia coli for immunization of rabbits, after purification. Western blotting revealed that this developed antiserum could effectively detect PLRV, but with better results from the perspective of color development and economics by using antiserum at the ratio range of 1:10000 to 1:40000, presenting high sensitivity and specificity to PLRV. The serological detection results for PLRV of the field samples were identical to the RT-PCR detection. This is the first report on the development of PLRV-MP antiserum that has been successfully used for both laboratory and field detection of PLRV. The results provide a fundamental tool for further research on the function of PLRV-MP.
\end{abstract}

Keywords: Potato leafroll virus, MP, Prokaryotic expression and purification, Antiserum development, Serological detection

\section{Background}

Potato (Solanum tuberosum L.) is one of the most important crops and is cultivated in more than 100 countries all over the world (He et al. 2012). It is infected by many pests, including at least 40 viruses and two viroids (Jeffries et al. 2006). One of the most severe viral diseases is caused by PLRV, which is distributed widely in the potato-growing areas of the world (Gillen and Novy 2007). PLRV is a representative species of the genus Polerovirus belonging to the family Luteoviridae (King et al. 2012) and was first described by Quanjer et al. in 1916 (Loebenstein et al. 2001). It is transmitted by aphids in a circulative non-propagative manner and is

\footnotetext{
* Correspondence: hanchenggui@cau.edu.cn

${ }^{\dagger}$ Fang Yang and M. Rashid contributed equally to this work.

State Key Laboratory for Agrobiotechnology and Key Laboratory of Pest Monitoring and Green Management, MOA, China Agricultural University, Beijing 100193, People's Republic of China
}

mainly restricted to the phloem tissues of infected plants (Mayo and Ziegler-Graff 1996; Lee et al. 2005). This viral disease is reportedly responsible for individual plant yield losses of over $50 \%$ and causes an annual global yield loss of 20 million tonnes (Wales et al. 2008). Primary symptoms of PLRV infection are yellowing of leaves, which may roll inward (Batool et al. 2011). Secondary symptoms in plants grown from infected potato tubers are stunting of shoot and leaflets rolling upwards, starting with the oldest leaves (Warren et al. 2005).

PLRV is a positive-sense single-stranded RNA virus comprising approximately $5.9 \mathrm{~kb}$ with six ORFs (open reading frame) encoding for proteins (King et al. 2012). The fourth ORF encodes a $17 \mathrm{kDa}$ phloem-limited protein (P4, or MP) that is associated with virus cell-to-cell movement (Sokolova et al. 1997) and also has a role in regulation of PLRV replication (Tacke et al. 1991). The PLRV-MP can form homodimers and this dimerization

(c) The Author(s). 2019 Open Access This article is distributed under the terms of the Creative Commons Attribution 4.0 International License (http://creativecommons.org/licenses/by/4.0/), which permits unrestricted use, distribution, and reproduction in any medium, provided you give appropriate credit to the original author(s) and the source, provide a link to the Creative Commons license, and indicate if changes were made. The Creative Commons Public Domain Dedication waiver (http://creativecommons.org/publicdomain/zero/1.0/) applies to the data made available in this article, unless otherwise stated. 
occurs in the N-terminus (Tacke et al. 1993). The PLRV-MP is phosphorylated near its C-terminus by a membrane-associated protein kinase, occurring in membranous structures possibly at the deltoid plasmodesmata (Sokolova et al. 1997).

Serology testing is one of the most important techniques widely used in plant virology for its specificity in disease diagnosis and relative ease of accomplishment (Derrick 1973; Lin et al. 1990). The effectiveness of a successful serological detection mostly depends on the availability and specificity of the antiserum. Most plant viruses contain MP genes in their genome that are associated with cell-to-cell movement of the virus through the plasmodesmata (Wolf et al. 1989; Haupt et al. 2005; Akamatsu et al. 2007). Anti-MP antisera used to detect these MPs in different plant viruses have been reported (Xie et al. 2007; Calegario et al. 2012; Li et al. 2015; Koolivand et al. 2016). As far as we know, there is no report on the preparation of PLRV-MP antiserum used for the detection of PLRV and its MP. Therefore, our study was conducted to purify bacterially-expressed recombinant PLRV-MP fusion protein and prepare its specific antiserum, which was successfully used to detect the MP in PLRV-infected plants.

\section{Results}

Prokaryotic expression and purification of PLRV-MP recombinant protein, and preparation of polyclonal antiserum

The PLRV-MP gene was amplified by PCR, and ligated with a prokaryotic expression vector pDB.His.MBP to produce pDB.His.MBP-PLRV-MP. Then the MP fusion protein was expressed in Escherichia coli (strain: BL21) and purified. During the prokaryotic expression and purification of PLRV-MP protein, the osmotic fluid was detected using Sodium Dodecyl Sulfate Polyacrylamide Gel Electrophoresis (SDS-PAGE). The results showed a specific protein band near the $67 \mathrm{kDa}$ protein marker (Fig. 1a), consistent with the size of the His.MBPPLRV-MP fusion protein (Fig. 1b), indicating that the fusion protein was successfully purified and the His.MBP tag was banded at $42 \mathrm{kDa}$ (Fig. 1b). Perhaps due to the rupture of the PLRV-MP and His.MBP tags, the fusion protein degraded during the purification process. The concentration of the fusion protein was approximately 2 $\mathrm{mg} / \mathrm{mL}$. The purified fusion protein $(4 \mathrm{~mL})$ was used to prepare the polyclonal antiserum in the Beijing Genomics Institute (Beijing, China), and a total of more than $50 \mathrm{~mL}$ of antiserum was obtained.

\section{Titer analysis}

The titer of PLRV-MP antiserum was analyzed by Western blotting with PLRV-infected Nicotiana benthamiana leaves. A weak protein band of $17 \mathrm{kDa}$ (Sokolova et al. 1997; Lee et al. 2002) was detectable down to an antiserum dilution of 1:1280000. From the viewpoint of color development, the antiserum functioned best at the ratio range of 1:10000 to 1:40000 (Fig. 2).

\section{Sensitivity analysis}

In order to analyze the sensitivity of the PLRV-MP antiserum (anti-MP ${ }^{\mathrm{PLRV}}$ ), proteins extracted from the PLRV-infected $N$. benthamiana leaves were serially diluted and subjected to Western blot analysis. When the total protein was diluted by 40 -fold, a positive band was clearly detected for the antiserum dilution factors 1:10000 and 1:20000 (Fig. 3a, b), while purified MP fusion protein of approximately $0.025 \mathrm{ng}$ could be detected with the antiserum diluted to 1:20000 (Fig. 3c).

\section{Specificity analysis}

Total protein was extracted from $N$. benthamiana leaves infected by PLRV, Turnip yellows virus (TuYV) and Brassica yellow virus (BrYV), respectively, and healthy leaf
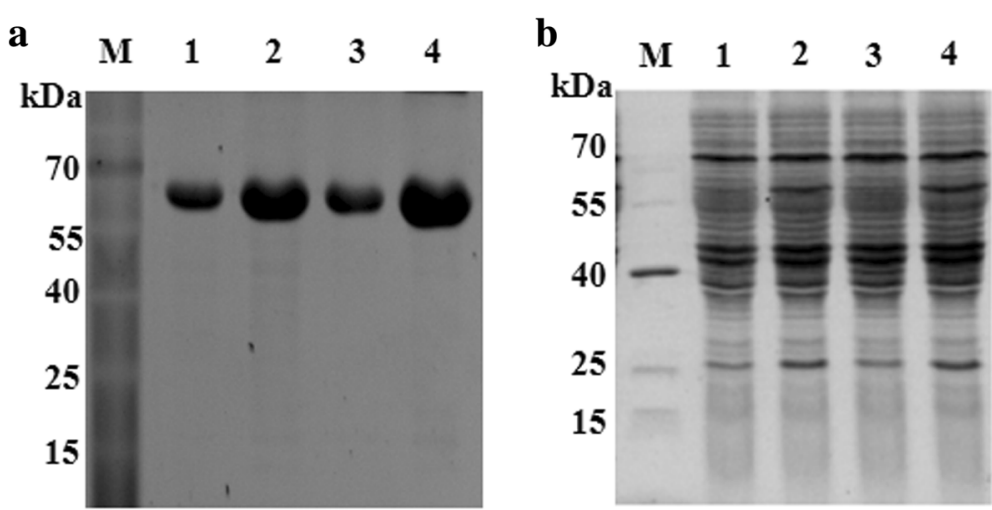

Fig. 1 SDS-PAGE analysis of PLRV-MP recombinant protein. a Lane M: PageRuler Prestained Protein Ladder, and lanes 1-4: Purified PLRV-MP recombinant protein. $\mathbf{b}$ Induced expression of PLRV-MP recombinant protein. Lanes 1, 3: Non-induced bacterial lysate, and lanes 2, 4: IPTG-induced lysate 


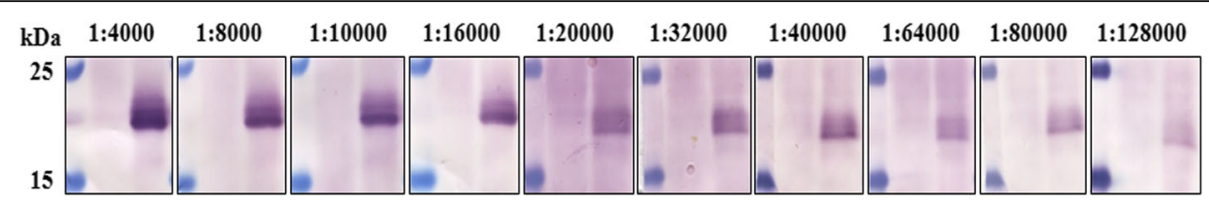

Fig. 2 Titer determination of PLRV-MP antiserum by Western blotting. Antiserum used at 10 different dilutions (1:4000, 1:8000, 1:10000, 1:16000, 1:20000, 1:32000, 1:40000, 1:64000, 1:80000, and 1:128000) against PLRV, each of which consists of a left lane of negative control and a right lane containing proteins extracted from PLRV-infected Nicotiana benthamiana leaves

was used as a negative control. Western blotting with anti-MP $^{\text {PLRV }}$ at ratios of 1:10000, 1:20000, and 1:30000 revealed positive results only in reactions with PLRVinfected N. benthamiana leaf (Fig. 4), indicating that the antiserum was specific to PLRV.

\section{Detection of PLRV from field samples using PLRV-MP antiserum and comparison with RT-PCR detection} Potato leaf samples from individual plants collected in Qianqin, Inner Mongolia were tested by Western blotting with anti-MP ${ }^{\text {PLRV }}$ at a ratio of 1: 20000 . The positive bands exhibited in three leaf samples were consistent with that of the positive control (PLRV-infected N. benthamiana leaf) (Fig. 5a) and identical to that of RT-PCR detection (Fig. 5b), indicating that this anti-MP ${ }^{\mathrm{PLRV}}$ was applicable for detection of PLRV in field crops.

\section{Discussion}

Protein expression is the way in which proteins are synthesized, modified and regulated in living organisms such as bacteria, yeast, plant or animal cells. The E. coli prokaryotic expression becomes a representative expression system as it has a clear genetic background, rapid reproduction, high expression levels, ease of purification of expression products, good stability, strong anti-pollution ability, low cost, and a wide range of applications (Hockney 1994). Many recombinant polyclonal antibodies specific to plant viruses have been previously generated for serological detection of viruses such as Tomato spotted wilt virus (Vaira et al. 1996), Potato virus $Y$ (Folwarczna et al. 2008), Alfalfa mosaic virus (Khatabi et al. 2012), and Wheat streak mosaic virus (Tatineni et al. 2014). Recombinant antisera for Egyptian isolates of both Potato virus $X$ (Soliman et al. 2006) and PLRV (Aseel and Hafez 2017; El-Attar et al. 2010) have also been produced. In our experiment, $E$. coli was used to express His.MBP-PLRV-MP from which PLRV-MP fusion protein was purified and anti-MP $P^{\text {PLRV }}$ successfully produced.

Viral MP plays an important role in the cell-to-cell movement of the infectious material. Recent research showed that the interaction of PLRV-MP with the protein 3a affected their localization to the mitochondria and plastids (DeBlasio et al. 2018). Serology is one of the

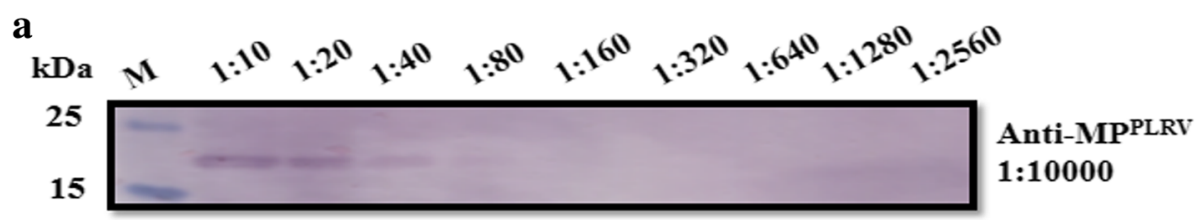

b

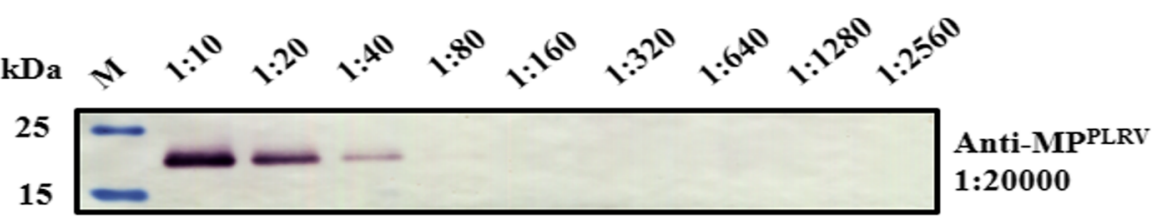

c

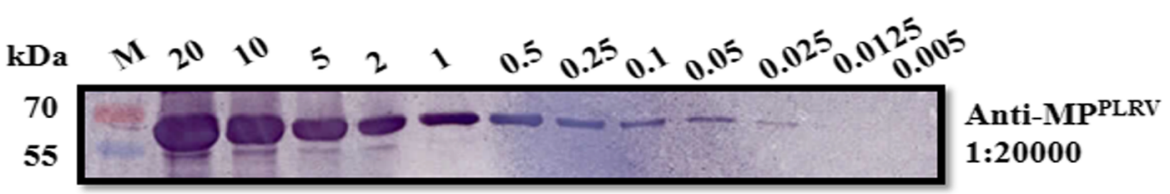

Fig. 3 Sensitivity analysis of PLRV-MP antiserum by Western blotting. a, b Lane M: PageRuler Prestained Protein Ladder, and the rest of the lanes show multiple dilutions of stock protein from the PLRV-infected Nicotiana benthamiana leaves (10-, 20-, 40-, 80-, 160-, 320-, 640-, 1280-, and 2560fold), with anti-MPPLV at the ratio of 1:10000 and 1:20000 respectively. $\mathbf{c}$ Lane M: PageRuler Prestained Protein Ladder, and the rest of the lanes show different concentrations of purified MP fusion protein $(20,10,5,2,1,0.5,0.25,0.1,0.05,0.025,0.0125$, and 0.005 ng), with antiserum at the ratio of 1:20000 


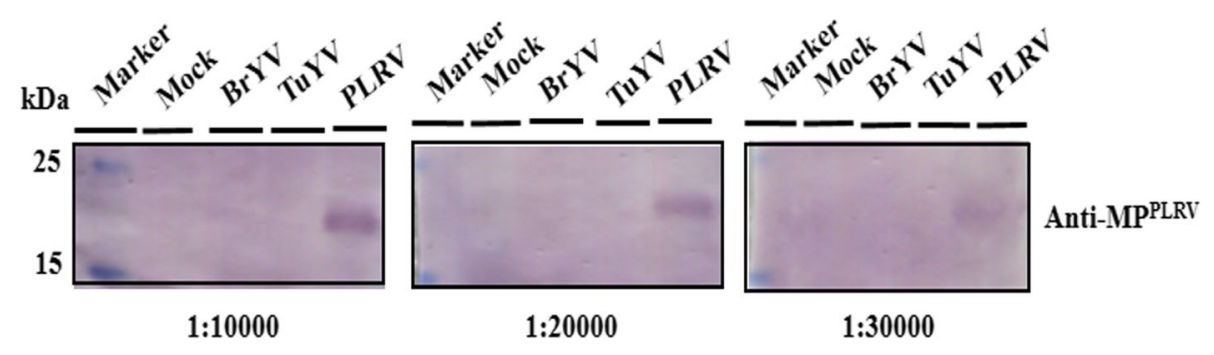

Fig. 4 Specificity analysis of PLRV-MP antiserum (anti-MPPLRV) by Western blotting. Marker: PageRuler Prestained Protein Ladder, Mock: protein extracted from the healthy leaf was used as a negative control, and the rest of the lanes are for the protein extracted from Nicotiana benthamiana leaves infected by Brassica yellow virus, Turnip yellows virus and Potato leafroll virus, respectively

most important techniques for virus detection (Aseel and Hafez 2017) and the antiserum (either monoclonal or polyclonal) is the basis for the serology test. In most cases, the anti-coat protein $(\mathrm{CP})$ antisera are used for virus detection; however, virus detection by the anti-CP antisera may not show whether the virus is in active (replication) or inactive stage. The positive detection of the MP with anti-MP antisera may indicate that the virus is in the multiplication stage. Polyclonal and monoclonal MP antibodies specific to Barley yellow dwarf virus (Xie et al. 2007; Li et al. 2015), polyclonal MP antibody specific to Citrus leprosis virus C (Calegario et al. 2012), and polyclonal MP antibody specific to Grapevine fanleaf virus (Koolivand et al. 2016) have been reported to detect the corresponding viruses, but most were effective only in laboratory use. Western blotting with anti-MP ${ }^{\text {PLRV }}$ in our study showed that the antiserum could detect PLRV efficiently, although ratios of 1:10000 to 1:40000 were better for color development. It was highly sensitive down to below $0.025 \mathrm{ng}$ of protein at the antiserum ratio of 1:30000 and strictly specific to PLRV. The antiserum could also detect PLRV from field samples and the detection result was identical to that of RT-PCR.

\section{Conclusions}

Because viral MP plays an important role in the process of virus infection, efforts to express PLRV-MP in E. coli and to produce a specific polyclonal antiserum against this protein will provide an important tool for identification of PLRV infection and further research on the localization, expression, interaction with host and various biochemical modifications of PLRV-MP are needed.

\section{Methods}

Plant material and growth conditions

Wild-type $N$. benthamiana plants were grown at $24 \pm 1{ }^{\circ} \mathrm{C}$ with a photoperiod of $16 / 8 \mathrm{~h}$ of light/dark cycle. Potato leaf samples were collected from Qianqi, Inner Mongolia.

\section{Construction of PLRV-MP prokaryotic expression vector}

The pT-PLRV-MP was constructed by amplification of pCa-PLRV containing the infectious cDNA clone of PLRV derived from the plasmid pBNUP110 (Franco-Lara et al. $1999)$ with the primer pair PLMPNdeF ( 5 '-CATATGTCA ATGGTGGTGTACAA-3') and PLMPXhoR (5'-CTCG AGTCATCCGCGCTTGATAAG-3'). The plasmids were then digested with $N d e I$ and $X h o I$ followed by ligation into

\section{a}

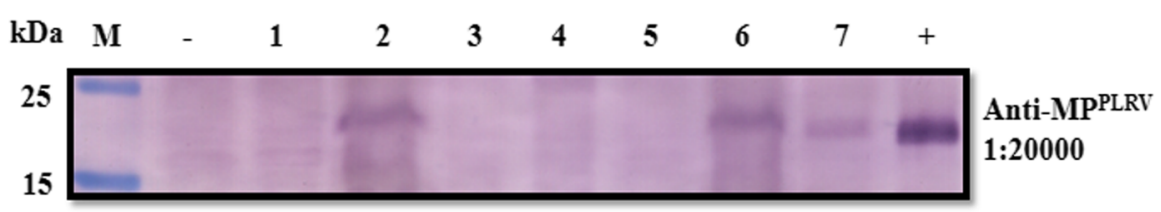

b

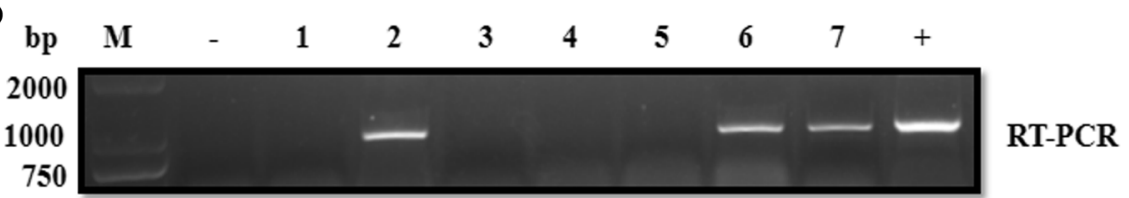

Fig. 5 Comparison of detections of PLRV from field crops using anti-MP ${ }^{P L R V}$ and RT-PCR. a Lane M: PageRuler Prestained Protein Ladder. b Lane M: DL2000 Ladder, lane "-": extract from healthy potato leaf (negative control), lanes 1-7: extracts from potato leaf samples collected from individual potato plants, lane "+": extract from PLRV-infected Nicotiana benthamiana leaf (positive control) 
the expression vector pDB.His.MBP (DNASU Plasmid Repository, Arizona, USA), and predigested with NdeI and $X h o \mathrm{I}$ to obtain the prokaryotic expression clone pDB.His.MBP-PLRV-MP containing the target gene.

\section{Prokaryotic expression and purification of PLRV-MP protein, and preparation of polyclonal antiserum} Oscillation culture of pDB.His.MBP-PLRV-MP was adjusted to an $\mathrm{OD}_{600}$ of 0.6-0.8. Isopropyl- $\beta$-D-thiogalactoside (IPTG; Sigma-Aldrich, St. Louis, MO, USA) was added to make a final concentration of $0.1 \mathrm{mM}$. After incubation at $18^{\circ} \mathrm{C}$ for $6 \mathrm{~h}$, it was centrifuged at $4000 \times \mathrm{g}$ for $10 \mathrm{~min}$. The cells were resuspended with high-salt buffer (20 mM Tris-HCl, $500 \mathrm{mM} \mathrm{NaCl}, \mathrm{pH} 8.0$ ) and centrifuged at $12,000 \times \mathrm{g}$ for $1 \mathrm{~h}$. The supernatants were collected on a Ni-affinity column (Qiagen, Hilden, Germany) and the proteins washed with elution buffer $(20 \mathrm{mM}$ Tris- $\mathrm{HCl}$, $150 \mathrm{mM} \mathrm{NaCl}, \mathrm{pH} 8.0$ ). Each purification process was subjected to SDS-PAGE and the appropriate eluent was concentrated to obtain the pDB.His.MBP-PLRV-MP fusion protein.

The purified fusion protein was sent to the Beijing Genomics Institute to prepare the polyclonal antiserum (anti-MP ${ }^{\text {PLRV }}$ ) by immunizing rabbits. Sensitivity and specificity of the antiserum developed against recombinant PLRV-MP were evaluated by Western blotting.

\section{Western blot detection}

Proteins were separated by SDS-PAGE using the protocol of Zhuo et al. 2014. Briefly, proteins were transferred to a nitrocellulose membrane (GE Healthcare, Buckinghamshire, UK) by electrotransfer (200 mA, $90 \mathrm{~min})$ with a mini trans-blot electrophoretic transfer cell (Bio-Rad, Hercules, CA, USA), and the nitrocellulose membranes were incubated in $1 \times$ TBST buffer $(20 \mathrm{mM}$ Tris- $\mathrm{HCl}$ $\mathrm{pH} 7.5,150 \mathrm{mM} \mathrm{NaCl}, 0.05 \%$ Tween-20) containing 5\% skim milk powder at $37^{\circ} \mathrm{C}$. After blocking for $1 \mathrm{~h}$, anti-MP ${ }^{\text {PLRV }}$ was added at a certain dilution and incubated at $37^{\circ} \mathrm{C}$ for $1 \mathrm{~h}$, and washed three times with $1 \times$ TBST for $10 \mathrm{~min}$ each time. The nitrocellulose membrane was then incubated with anti-rabbit in goat (IgG; Sigma-Aldrich) diluted at $1: 3000$ for $1 \mathrm{~h}$ at $37^{\circ} \mathrm{C}$ as a secondary antibody followed by washing with $1 \times$ TBST. The band was visualized by using nitro-blue tetrazolium and 5-bromo-4-chloro-3-indolyphosphate (Sigma-Aldrich).

\section{Determination of anti-MP ${ }^{\text {PLRV }}$ titer}

Total protein was extracted from PLRV-infected $N$. benthamiana leaves and healthy $N$. benthamiana leaf (as a negative control) as described by Zhuo et al. 2014. Anti-MP ${ }^{\text {PLRV }}$ with a dilution factor of 4000,8000 , $10000,16000,20000,32000,40000,64000,80000$, and 128000 was used in Western blotting to determine the titer value.

\section{Sensitivity analysis of the anti-MP $P^{\text {PLRV }}$}

The experiment was performed by extracting the total protein from PLRV-infected N. benthamiana leaves and multiple dilution samples were prepared by diluting the stock sample multiples of 10, 20, 40, 80, 160, 320, 640, 1280 , and 2560 with protein extraction buffer. Western blotting was performed using anti-MP ${ }^{\mathrm{PLRV}}$ at the ratio of 1:10000 and 1:20000 respectively.

Another experiment was performed by loading 20, 10, $5,2,1,0.5,0.25,0.1,0.05,0.025,0.0125$, and $0.005 \mathrm{ng}$ of purified protein respectively and anti-MP ${ }^{\text {PLRV }}$ was diluted at the ratio of 1:20000.

\section{Anti-MPPLRV specificity analysis}

Total protein was extracted from $N$. benthamiana leaves infected by BrYV, TuYV and PLRV respectively with healthy leaf as a negative control. Specificity of the antiserum was detected by Western blotting.

\section{Field application of the antiserum}

Leaf samples collected from individual standing field potato plants in Qianqi, Inner Mongolia, were tested for PLRV detection using our newly developed anti-MP ${ }^{\text {PLRV }}$, with healthy leaf sample as a negative control and PLRV-infected N. benthamiana leaf as a positive control. The result was compared with RT-PCR detection results.

\section{Abbreviations \\ BrYV: Brassica yellow virus; CP: Coat protein; IPTG: Isopropyl- $\beta-D-$ thiogalactoside; MP: Movement protein; ORF: Open reading frame; PLRV: Potato leafroll virus; RT-PCR: Reverse transcription polymerase chain reaction; SDS-PAGE: Sodium Dodecyl Sulphate Polyacrylamide Gel Electrophoresis; TBST: Tris-buffered saline; TuW: Turnip yellow virus}

\section{Acknowledgments}

We thank Professor Peter Palukaitis (Seoul Women's University) for providing the plasmid pBNUP110 containing the infectious CDNA clone of PLRV, Dr. David Baulcombe (John Innes Centre, UK) for providing N. benthamiana plants and Dr. Salah Bouzoubaa (University of Strasbourg, France) for providing E. coli strain MC1022.

\section{Funding}

This work was supported by the National Natural Science Foundation of China (31671995 and 31371909) and the 111 project (B13006).

\section{Availability of data and materials \\ The datasets used and/or analyzed during the current study are available from the corresponding author on reasonable request.}

\section{Authors' contributions}

C-GH conceived the study and revised the manuscript. FY and MR performed the experiments. FY drafted the manuscript and MR wrote the manuscript. X-YZ constructed a plasmid. ZYZ, YW, DWL and JLY contributed reagents/materials/ analysis tools. All authors read and approved the final manuscript.

Ethics approval and consent to participate Not applicable

Consent for publication Not applicable 


\section{Competing interests}

The authors declare that they have no competing interests.

Received: 17 September 2018 Accepted: 20 January 2019

Published online: 08 February 2019

\section{References}

Akamatsu N, Takeda A, Kishimoto M, Kaido M, Okuno T, Mise K. Phosphorylation and interaction of movement protein and coat proteins of Brome mosaic virus in infected barley protoplasts. Arch Virol. 2007;152:2087-93.

Aseel DG, Hafez EE. The comparison of antibodies raised against PLRV with two different approaches- viral particles purification and recombinant production of CP. J Plant Pathol Microbiol. 2017;8:407. https://doi.org/10.4172/2157-7471. 1000407.

Batool A, Khan MA, Farooq J, Mughal SM, Iftikhar Y. Elisa-based screening of potato germplasm against Potato leafroll virus. J Agric Res. 2011;49:57-63.

Calegario RF, Labate MTV, Peroni LA, Stach-Machado DR, Andrade MO, FreitasAstúa J, et al. In vitro expression and antiserum production against the movement protein of Citrus leprosis virus C (CiLV-C). Trop Plant Pathol. 2012; 37:136-41.

DeBlasio SL, Xu Y, Johnson RS, Rebelo AR, MacCoss MJ, Gray SM, et al. The interaction dynamics of two Potato leafroll virus movement proteins affects their localization to the outer membranes of mitochondria and plastids. Viruses. 2018;10:585. https://doi.org/10.3390/v10110585.

Derrick KS. Quantitative assay for plant viruses using serologically specific electron microscopy. Virology. 1973:56:652-3.

El-Attar AK, Riad BY, Saad A, Soliman AM, Mazyad HM. Expression of the coat protein gene of Potato leafroll virus in Escherichia coli and development of polyclonal antibodies against recombinant coat protein. Arab J Biotech. 2010; 13:85-98.

Folwarczna J, Plchová H, Moravec T, Hoffmeisterová H, Dedic P, Cerovská N. Production of polyclonal antibodies to a recombinant coat protein of Potato virus Y. Folia Microbiol (Praha). 2008:53:438-42.

Franco-Lara LF, McGeachy KD, Commandeur U, Martin RR, Mayo MA, Barker H. Transformation of tobacco and potato with cDNA encoding the full-length genome of Potato leafroll virus: evidence for a novel virus distribution and host effects on virus multiplication. J Gen Virol. 1999:80:2813-22.

Gillen AM, Novy RG. Molecular characterization of the progeny of Solanum tuberosum identifies a genomic region associated with resistance to Potato leafroll virus. Euphytica. 2007;155:403-15.

Haupt S, Cowan GH, Ziegler A, Roberts AG, Oparka KJ, Torrance L. Two plant-viral movement proteins traffic in the endocytic recycling pathway. Plant Cell. 2005;17:164-81.

He Z, Larkin R, Honeycutt W, editors. Sustainable potato production: global case studies. 1st ed. Dordrecht: Springer; 2012

Hockney RC. Recent developments in heterologous protein production in Escherichia coli. Trends Biotechnol. 1994;12:456-63.

Jeffries C, Barker H, Khurana SMP. Potato viruses (and viroids) and their management. In: Gopal J, Khurana SMP, editors. Handbook of potato production, improvement and post-harvest management. New York: The Haworth's food products press; 2006. p. 387-448.

Khatabi B, He B, Hajimorad MR. Diagnostic potential of polyclonal antibodies against bacterially expressed recombinant coat protein of Alfalfa mosaic virus. Plant Dis. 2012;96:1352-7

King AMQ, Adams MJ, Carstens EB, Lefkowitz EJ. Virus taxonomy: classification and nomenclature of viruses: ninth report of the international committee on taxonomy of viruses. San Diego: Academic Press, Elsevier; 2012

Koolivand D, Bashir NS, Behjatnia SA, Joozani RJ. Production of polyclonal antibody against Grapevine fanleaf virus movement protein expressed in Escherichia coli. Plant Pathol J. 2016;32:452-9.

Lee L, Kaplan IB, Ripoll DR, Liang D, Palukaitis P, Gray SM. A surface loop of the potato leafroll virus coat protein is involved in virion assembly, systemic movement, and aphid transmission. J Virol. 2005:1207-14.

Lee L, Palukaitis P, Gray SM. Host-dependent requirement for the Potato leafroll virus 17 kDa protein in virus movement. Mol Plant Microbe Inter. 2002;15:1086-94.

Li N, Chen Z, Liu Y, Liu Y, Zhou X, Wu J. Development of monoclonal antibodies and serological assays specific for Barley yellow dwarf virus GAV strain. Virol J. 2015;12:136-44.

Lin NS, Hsu YH, Hsu HT. Immunological detection of plant viruses and a mycoplasma-like organism by direct tissue blotting on nitrocellulose membranes. Phytopathology. 1990;80:824-8.
Loebenstein G, Berger PH, Brunt AA, Lawson RH. Virus and virus-like diseases of potatoes and production of seed potatoes. Netherlands: Kluwer Academic Publishers; 2001. p. 69-72.

Mayo MA, Ziegler-Graff V. Molecular biology of luteoviruses. Adv Virus Res. 1996; 46:413-60.

Sokolova M, Prufer D, Tacke E, Rohde W. The potato leafroll virus $17 \mathrm{kDa}$ movement protein is phosphorylated by a membrane-associated protein kinase from potato with biochemical features of protein kinase C. FEBS Lett. 1997:400:201-5.

Soliman AM, Barsoum BN, Mohamed GG, El-Attar AK, Mazyad HM. Expression of the coat protein gene of the Egyptian isolate of Potato virus $X$ in Escherichia coli and production of polyclonal antibodies against it. Arab J Biotech. 2006; 9:115-28.

Tacke E, Prufer D, Schmitz J, Rohde W. The potato leafroll luteovirus $17 \mathrm{~K}$ protein is a single-stranded nucleic acid-binding protein. J Gen Virol. 1991;72:2035-8.

Tacke E, Schmitz J, Prufer D, Rohde W. Mutational analysis of the nucleic acidbinding $17 \mathrm{kDa}$ phosphoprotein of Potato leafroll luteovirus identifies an amphipathic a-helix as the domain for protein-protein interactions. Virology. 1993;197:274-82.

Tatineni S, Kovacs F, French R. Wheat streak mosaic virus infects systemically despite extensive coat protein deletions: identification of virion assembly and cell-to-cell movement determinants. J Virol. 2014:88:1366-80.

Vaira AM, Vecchiati M, Masenga V, Accotto GP. A polyclonal antiserum against a recombinant viral protein combines specificity with versatility. J Virol Methods. 1996:56:209-19.

Wales S, Platt HW, Cattlin N. Diseases, pests and disorders of potatoes. London: Manson Publishing Ltd; 2008. p. 75-6.

Warren M, Kruger K, Schoeman AS. Potato virus Y (PVY) and Potato leafroll virus (PLRV): literature review for potatoes South Africa. Pretoria: Department of Zoology and Entomology, Faculty of Natural and Agricultural Sciences, University of Pretoria; 2005

Wolf S, Deom CM, Beachy RN, Lucas WJ. Movement protein of Tobacco mosaic virus modifies plasmodesmatal size exclusion limit. Science. 1989;246:377-9.

Xie JJ, Wang XF, Liu Y, Peng YF, Zhou GH. Expression, purification and antiserum preparation of BYDV GAV movement protein, and its application. In: Peng YL, Kang ZS, editors. Proceeding of the annual meeting of Chinese society for plant pathology. Yangling: Northwest A\&F University Press; 2007. p. 215-7. in Chinese.

Zhuo T, Li YY, Xiang HY, Wu ZY, Wang XB, Wang Y, et al. Amino acid sequence motifs essential for P0-mediated suppression of RNA silencing in an isolate of Potato leafroll virus from Inner Mongolia. Mol Plant Microbe Inter. 2014;27: 515-27.
Ready to submit your research? Choose BMC and benefit from:

- fast, convenient online submission

- thorough peer review by experienced researchers in your field

- rapid publication on acceptance

- support for research data, including large and complex data types

- gold Open Access which fosters wider collaboration and increased citations

- maximum visibility for your research: over $100 \mathrm{M}$ website views per year

At BMC, research is always in progress.

Learn more biomedcentral.com/submissions 